2. To: (Receiving Organization) Packaging Safety Engineering

5. Proj./Prog./Dept./Div.:

Transportation and Packaging

8. Originator Remarks:

For clearance and release
3. From: (Originating Organization) Nuclear Physics and Shielding 6. Cog. Engr.:

J. V. Nelson

1. EDT 603245

4. Related EDT No.:

603245

7. Purchase Order No.:

NA

9. Equip./Component No.:

NA

10. System/Bldg./Facility:

12. Major Assm. Dwg. No.:

NA

13. Permit/Permit Application No.: NA

14. Required Response Date:

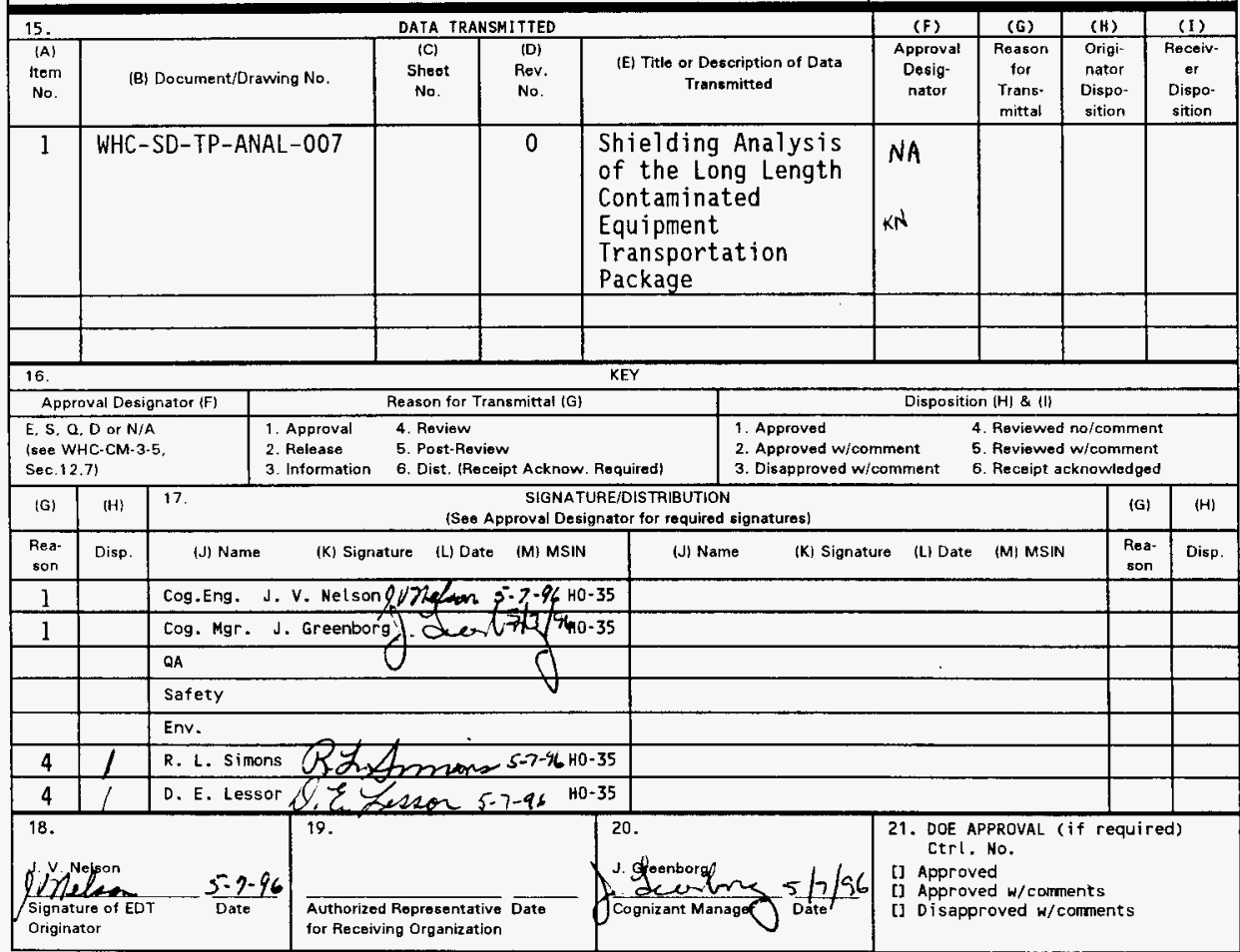

BD-7400-172-2 (04/94) GEF097 


\section{Shielding Analysis of the Long Length Contaminated Equipment Transportation Package}

Joseph V. Nelson

Westinghouse Hanford Company, Richland, WA 99352

U.S. Department of Energy Contract DE-AC06-87RL10930

EDT/ECN: $603245 \quad$ UC: 513

Org Code: 8M730 Charge Code: N1782

B\&R Code: EW3130010 Total Pages: $19 \mathrm{kN}$

Key Words: Long length equipment, transportation package, shielding analysis, nuclear waste

Abstract: A shielding analysis of a potential long length contaminated equipment transportation package was completed. The analysis was performed to support the design of the transportation package and external shielding.

TRADEMARK DISCLAIMER. Reference herein to any specific commercial product, process, or service by trade name, trademark, manufacturer, or otherwise, does not necessarily constitute or imply its endorsement, recommendation, or favoring by the United States Government or any agency thereof or its contractors or subcontractors.

Printed in the United States of America. To obtain copies of this document, contact: UHC/BCS Document Control Services, P.O. Box 1970, Mailstop H6-08, Richland WA 99352, Phone (509) 372-2420; Fax (509) 376-4989.
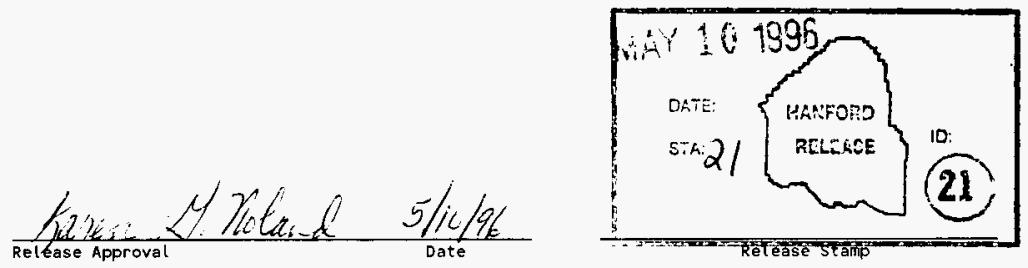

\section{Approved for Public Release}


WHC-SD-TP-ANAL-007

Rev. 0

Page 2 of 17

\section{SHIELDING ANALYSIS OF THE LONG LENGTH CONTAMINATED EQUIPMENT TRANSPORTATION PACKAGE}

\subsection{INTRODUCTION}

This report presents the results of a preliminary analysis of dose rates around a potential long length contaminated equipment (LLCE) transportation package. The analysis was completed to support the design of this transportation package and external shielding.

The transportation package consists of a long polyethylene container, $21.3 \mathrm{~m}$ $(70 \mathrm{ft}$ ) in length. Inside this pipe is a steel half-shell pipe used as a skid for the LLCE. A variety of LLCE must be accommodated by the packaging. The length of this equipment ranges from $3.6 \mathrm{~m}(12 \mathrm{ft})$ to $18.9 \mathrm{~m}(62 \mathrm{ft})$. The source term used in the shielding analysis of the proposed LLCE shipments was based on a worst-case evaluation.

\subsection{DIRECT RADIATION SOURCE SPECIFICATION}

The worst-case source term used in this analysis was the one used previousiy in the safety class analysis of LLCE packaging (Ref. 1). This source is listed in Table 1.

\subsection{Gamma Source}

The source term 1 isted in Table 1 was used as input to the ISOSHLD program (Ref. 2) to compute a photon source rate as a function of photon energy. The resulting energy distribution is listed in Table 2. The total source rate was computed by ISOSHLD to be $4.68 \times 10^{13}$ photons $/ \mathrm{sec}$.

\subsection{Beta Source}

The beta source within the loaded LLCE container leads to an insignificant dose rate outside the perimeter of the trailer because of the shielding provided by steel in the LLCE, the steel skid plate, the grout filler, the polyethylene container, the trailer deck and external shielding. This shielding is described in Section 4.0.

\subsection{Neutron Source}

Actinides listed in Table 1 are in very low concentrations. Thus, neutron dose rates were expected to be negligible compared to photon dose rates. This was confirmed using the method described in Reference 3 to conservatively estimate neutron doses at several locations around the trailer. Since the neutron dose rates are insignificant, they are not reported. 
WHC-SD-TP-ANAL-007

Rev. 0

Page 3 of 17

Table 1. Radionuclide Inventory in the LLCE

\begin{tabular}{|c|c|c|}
\hline \multirow[t]{2}{*}{ Isotope } & \multicolumn{2}{|c|}{ Activity" } \\
\hline & $\mathrm{Bq}$ & $\mathrm{Ci}$ \\
\hline${ }^{14} \mathrm{C}$ & $2.25 E+09$ & $6.07 E-02$ \\
\hline${ }^{60} \mathrm{Co}$ & $1.23 E+12$ & $3.32 \mathrm{E}+01$ \\
\hline${ }^{63} \mathrm{Ni}$ & $3.63 E+10$ & $9.81 E-01$ \\
\hline${ }^{79} \mathrm{Se}$ & $9.03 E+07$ & $2.44 E-03$ \\
\hline${ }^{90} \mathrm{Sr}$ & $7.70 \mathrm{E}+12$ & $2.08 \mathrm{E}+02$ \\
\hline $90_{Y}$ & $7.70 \mathrm{E}+12$ & $2.08 E+02$ \\
\hline $93 \mathrm{~m} \mathrm{Nb}$ & $2.22 E+08$ & $6.01 E-03$ \\
\hline${ }^{93} \mathrm{zr}$ & $3.24 E+08$ & $8.77 \mathrm{E}-03$ \\
\hline${ }^{95} 2 r$ & $2.80 E+11$ & $7.57 \mathrm{E}+00$ \\
\hline${ }^{99} \mathrm{TC}$ & $5.14 E+10$ & $1.39 E+00$ \\
\hline${ }^{106}{ }_{R h}$ & $3.22 E+11$ & $8.70 E+00$ \\
\hline $106_{\mathrm{Ru}}$ & $3.22 E+11$ & 8. $70 \mathrm{E}+00$ \\
\hline${ }^{125} \mathrm{sb}$ & $1.95 E+11$ & $5.27 E+00$ \\
\hline $129_{1}$ & $3.15 E+07$ & $8.52 E-04$ \\
\hline${ }^{134} \mathrm{cs}$ & $5.14 E+10$ & $1.39 \mathrm{E}+00$ \\
\hline $137_{\mathrm{Cs}}$ & $3.37 E+13$ & $9.10 \mathrm{E}+02$ \\
\hline $137 \mathrm{~m}_{\mathrm{Ba}}$ & $3.19 E+13$ & $8.61 E+02$ \\
\hline${ }^{144} \mathrm{Ce}$ & $1.57 E+13$ & $4.24 \mathrm{E}+02$ \\
\hline${ }^{144} \mathrm{Pr}$ & $1.57 E+13$ & $4.24 E+02$ \\
\hline $147_{\mathrm{Pm}}$ & $5.85 \mathrm{E}+09$ & $1.58 \mathrm{E}-01$ \\
\hline${ }^{151} \mathrm{Sm}$ & $6.22 E+10$ & $1.68 \mathrm{E}+00$ \\
\hline $154 / 155_{\mathrm{EU}}$ & 4. $18 E+10$ & 1. $13 E+00$ \\
\hline $233_{\mathrm{U}}$ & $9.29 E+06$ & $2.51 E-04$ \\
\hline${ }^{234} \mathrm{U}$ & $8.58 E+03$ & $2.32 \mathrm{E}-0 ?$ \\
\hline $235 \mathrm{u}$ & $2.58 E+06$ & $6.98 \mathrm{E}-05$ \\
\hline $237_{\mathrm{Np}}$ & $1.10 E+07$ & $2.96 \mathrm{E}-04$ \\
\hline $238_{\mathrm{NP}}$ & $7.07 E+04$ & $1.91 \mathrm{E}-06$ \\
\hline $238_{\mathrm{Pu}}$ & $2,86 \mathrm{E}+08$ & $7.72 E-03$ \\
\hline $238_{\mathrm{U}}$ & $6.25 \mathrm{E}+07$ & $1.69 \mathrm{E}=03$ \\
\hline $239^{\mathrm{Pu}}$ & $1.48 E+10$ & $4.00 E-01$ \\
\hline $240 \mathrm{Pu}$ & $6.88 \mathrm{E}+08$ & $1.86 E-02$ \\
\hline $241_{\mathrm{Am}}$ & $1.36 E+10$ & $3.67 \mathrm{E}-01$ \\
\hline${ }^{241} \mathrm{Pu}$ & $6.62 E+09$ & $1.79 E-01$ \\
\hline $242_{\mathrm{Am}}$ & $1.41 E+07$ & $3.81 E-04$ \\
\hline${ }^{242} \mathrm{~cm}$ & $4.26 E+07$ & $1.15 E-03$ \\
\hline $242 \mathrm{~m}_{\mathrm{Am}}$ & 1. $42 E+07$ & $3.83 E-04$ \\
\hline${ }^{242} \mathrm{Pu}$ & $4.48 E+01$ & $1.21 E-09$ \\
\hline $243_{\mathrm{Am}}$ & $4.03 E+08$ & $1.09 E-02$ \\
\hline${ }^{244} \mathrm{~cm}$ & $5.85 \mathrm{E}+07$ & $1.58 E-03$ \\
\hline
\end{tabular}

* The format of the activities is z.dEtee, which is interpreted as z.d $\times 10^{ \pm \text {ee }}$. 
WHC-SD-TP-ANAL-007

Rev. 0

Page 4 of 17

Table 2. Photon Source Rate Energy Distribution

\begin{tabular}{||cc||}
\hline $\begin{array}{c}\text { Average } \\
\text { Energy } \\
\text { (MeV) }\end{array}$ & $\begin{array}{c}\text { Photon } \\
\text { Source Rate* } \\
\text { (photons } / \text { sec) }\end{array}$ \\
\hline 0.015 & $2.496 \mathrm{E}+12$ \\
0.025 & $1.372 \mathrm{E}+12$ \\
0.035 & $4.253 \mathrm{E}+12$ \\
0.045 & $8.709 \mathrm{E}+11$ \\
0.055 & $4.149 \mathrm{E}+11$ \\
0.065 & $3.177 \mathrm{E}+11$ \\
0.075 & $2.618 \mathrm{E}+11$ \\
0.085 & $4.993 \mathrm{E}+11$ \\
0.095 & $2.149 \mathrm{E}+11$ \\
0.150 & $3.002 \mathrm{E}+12$ \\
0.250 & $3.994 \mathrm{E}+11$ \\
0.350 & $2.002 \mathrm{E}+11$ \\
0.475 & $2.977 \mathrm{E}+11$ \\
0.550 & $2.928 \mathrm{E}+13$ \\
0.825 & $2.412 \mathrm{E}+11$ \\
1.000 & $3.261 \mathrm{E}+10$ \\
1.225 & $2.476 \mathrm{E}+12$ \\
1.475 & $5.809 \mathrm{E}+10$ \\
1.700 & $2.796 \mathrm{E}+09$ \\
1.900 & $1.189 \mathrm{E}+09$ \\
2.100 & $1.213 \mathrm{E}+11$ \\
2.300 & $1.935 \mathrm{E}+08$ \\
2.500 & $5.875 \mathrm{E}+07$ \\
2.700 & $1.282 \mathrm{E}+07$ \\
3.000 & $2.542 \mathrm{E}+06$ \\
3.600 & $1.198 \mathrm{E}+05$ \\
\hline Total & $4.681 \mathrm{E}+13$ \\
\hline
\end{tabular}

- The format of the source rate data is z.dEzee, which is interpreted as $z . d \times 10^{ \pm e e}$.

\subsection{CALCULATIONAL METHOD}

Al1 dose rate calculations were made using the Hanford version (Ref. 4) of the Monte Carlo code MCNP (Ref. 5). For expediency, initial scoping calculations were made using the point-kernel option in the code. However, any contribution to a dose rate from ground shine cannot be quantified using the point-kernel method. Because of the minimal amount of shielding on the bottom of the transportation package, final MCNP calculations were made using the rigorous transport mode to account for ground shine. Unless noted otherwise, results presented in Sections 5.0 and 6.0 are from the transport calculations. Dose rates were tallied in MCNP using the point detector option.

In all cases, photon cross section data from the ENDF/B-V Tibrary were used, and photon fluxes were converted to dose rates using ANSI/ANS-6.1.1-1991 fluence-to-dose conversion factors.

Results from Monte Carlo calculations are subject to statistical uncertainties. MCNP provides an estimate of the uncertainty for each computed dose rate. However, there is a statistical uncertainty on this estimate. When using point detectors to tally dose rates, MCNP uncertainties estimated to be less than $5 \%$ are generally reliable. Uncertainty estimates in the $5 \%$ to $10 \%$ range tend to be reasonably reliable, but should be treated with caution. 
WHC-SD-TP-ANAL-007

Rev. 0

Page 5 of 17

For uncertainties larger than $10 \%$, there can be a large uncertainty in the given uncertainty, and results should be treated as, at most, order of magnitude estimates.

\subsection{CALCULATIONAL MODELS}

The LLCE container was represented as a long polyethylene pipe lying on a steel flat-bed trailer. A plan view of the calculational model is shown in Figure 1, and a cross section of the model is shown in Figure 2.

The pipe was modeled as having a length of $21.3 \mathrm{~m}(70.0 \mathrm{ft})$, an outer diameter (OD) of $170.2 \mathrm{~cm}(67.0 \mathrm{in.})$ and a wall thickness of $3.18 \mathrm{~cm}(1.25 \mathrm{in}$.). A polyethylene end cap $4.93 \mathrm{~cm}$ (1.94 in.) thick was included at each end of the pipe. Inside the polyethylene container is a steel half-shell pipe used as a skid for the LLCE. The skid has an $O D$ of $149.5 \mathrm{~cm}$ (58.9 in.) and a thickness of $0.48 \mathrm{~cm}(0.19 \mathrm{in}$.$) . It runs the length of the polyethylene container, and$ includes steel end plates $0.48 \mathrm{~cm}(0.19 \mathrm{in.})$ thick.

The LLCE, which sits on the bottom of the skid, was represented as a column of steel pipe having a length of $18.9 \mathrm{~m}(62.0 \mathrm{ft})$, an 00 of $108.0 \mathrm{~cm}(42.5 \mathrm{in}$. and a wall thickness of $0.64 \mathrm{~cm}(0.25$ in.). The pipe was modeled as containing $9.1 \mathrm{~m}(30.0 \mathrm{ft})$ of uniformly distributed tank waste at one end, with the remaining $9.8 \mathrm{~m}(32.0 \mathrm{ft})$ voided. The end with the radioactive source material was located at the front of the trailer. The space around the LLCE inside the polyethylene container was filled with low density $(0.32 \mathrm{~g} / \mathrm{CC})$ grout, which is intended to provide stability and shielding.

The steel trailer bed was modeled as being $23.2 \mathrm{~m}(76.0 \mathrm{ft})$ long, $287 \mathrm{~cm}$ (113.0 in.) wide and $0.64 \mathrm{~cm}(0.25 \mathrm{in.})$ thick. The top of the trailer bed was set at $228.6 \mathrm{~cm}(90.0 \mathrm{in}$.) above ground level. The polyethylene container was positioned $33.9 \mathrm{~cm}(13.3 \mathrm{in.})$ from the back of the trailer.

External steel shields on all four sides of the trailer are planned. Along each side of the polyethylene container is a steel plate that runs the length of the container $(21.3 \mathrm{~m}$, or $70.0 \mathrm{ft})$. Each plate, mounted on top of the trailer bed, is $1.27 \mathrm{~cm}(0.50$ in.) thick and $111.8 \mathrm{~cm}(44.0 \mathrm{in.})$ tal1.

A steel plate was also included in the model directly in front of the polyethylene container. This plate, $152 \mathrm{~cm}(60.0 \mathrm{in}$.) square and $1.27 \mathrm{~cm}$ $(0.50 \mathrm{in.}$.) thick, is intended to stabilize the load and provide needed shielding. Additional shielding to the driver is provided by another steel plate located at the front edge of the trailer. This shield is $182.9 \mathrm{~cm}(72.0$ in.) tall and extends the width of the trailer. The shield thickness was varied from $2.54 \mathrm{~cm}(1.0 \mathrm{in.})$ to $12.7 \mathrm{~cm}(5.0 \mathrm{in.})$ to determine the effect of shield thickness on the dose rate at the truck driver's location, assumed to be $152 \mathrm{~cm}(60 \mathrm{in.})$ in front of the trailer.

A $2.54 \mathrm{~cm}$ (1.0 in.) thick guillotine shield is located at the rear of the trailer to protect workers while the back cover is placed on the polyethylene pipe, and the container void is filled with low density grout. This shield is $213.4 \mathrm{~cm}$ ( $84.0 \mathrm{in.}$ ) tall, and runs the width of the trailer. To provide access to the container, there is an opening in the top-center portion of the shield. This opening is $170.2 \mathrm{~cm}(67.0 \mathrm{in.})$ wide and begins $21.7 \mathrm{~cm}$ ( 8.5 in.) above the trailer deck.

The ground was modeled as a concrete surface. All air spaces were modeled as voided regions. Thus, while ground shine was accounted for in the model, the effect of photon scattering in air (sky shine) was not. Compositions for all materials used in the calculational model are given in Table 3 . 
WHC-SD-TP-ANAL-007

Rev. 0

Page 6 of 17

6' high shield

(variable thickness)

steel plate

(5' $\left.\times 5^{\prime} \times 0.5^{\prime \prime}\right)$

side shield

skid

trailer bed

container

guillotine shield

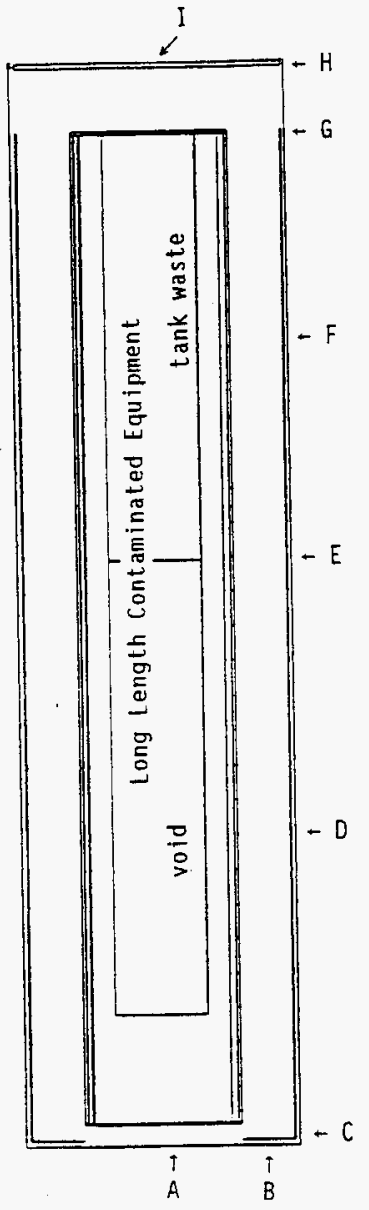

Letters A - I indicate locations where dose rates were computed. Dose rates were also computed at the driver location.

Figure 1. Plan View of MCNP Calculational Model 
WHC-SD-TP-ANAL-007

Rev. 0

Page 7 of 17

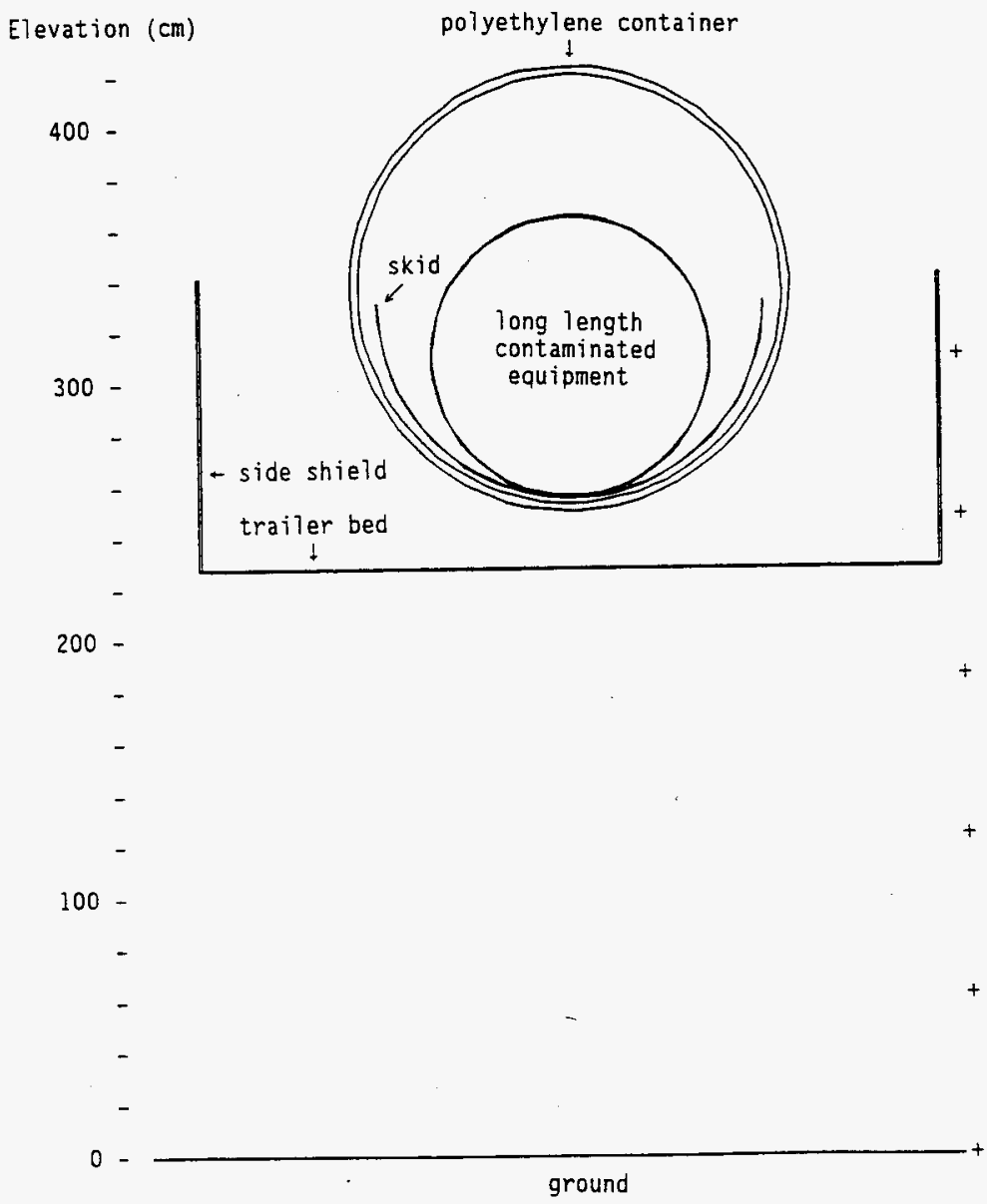

$+=$ elevations at which dose rates were tallied

Figure 2. Cross Section of MCNP Calculational Model 
WHC-SD-TP-ANAL-007

Rev. 0

Page 8 of 17

Table 3. Material Compositions

\begin{tabular}{||ccc|}
\hline $\begin{array}{l}\text { Material } \\
\text { (density) }\end{array}$ & Element & $\begin{array}{c}\text { Weight } \\
\text { Fraction }\end{array}$ \\
\hline Steel & $\mathrm{Fe}$ & 1.000 \\
(7.8g/cc) & $\mathrm{H}$ & 0.143 \\
Polyethylene & $\mathrm{C}$ & 0.857 \\
(0.95 g/cc) & $\mathrm{H}$ & 0.043 \\
Tank Waste & $\mathrm{C}$ & 0.020 \\
(1.6 g/cc) & $\mathrm{N}$ & 0.079 \\
& 0 & 0.584 \\
& $\mathrm{Na}$ & 0.220 \\
& $\mathrm{Al}$ & 0.030 \\
& $\mathrm{P}$ & 0.003 \\
& $\mathrm{Cl}$ & 0.010 \\
$\mathrm{~K}$ & 0.010 \\
\hline Low-Density Grout & 0 & 0.441 \\
(0.32 g/cc) & $\mathrm{Si}$ & 0.216 \\
\& & $\mathrm{Ca}$ & 0.131 \\
Concrete & $\mathrm{Fe}$ & 0.079 \\
(2.28 g/cc) & $\mathrm{Al}$ & 0.061 \\
& $\mathrm{Mg}$ & 0.038 \\
& $\mathrm{~K}$ & 0.007 \\
& $\mathrm{Na}$ & 0.018 \\
& $\mathrm{Ti}$ & 0.005 \\
& $\mathrm{H}$ & 0.003 \\
& $\mathrm{Mn}$ & 0.001 \\
& $\mathrm{P}$ & 0.001 \\
& $\mathrm{~S}$ & 0.001 \\
\hline
\end{tabular}

\subsection{RESULTS}

Dose rates were computed for points at the front, back and side of the trailer, including the approximate driver location. The locations where dose rates were computed are indicated in Figure 1 . Points $A$ and $B$ are behind the trailer. Point $A$ is at the back-center of the trailer where the opening in the guillotine shield is, while point $B$ is behind the tall section of this shield. Points $C$ through $H$ are along the side of the trailer, and point $I$ is at the front-center of the trailer. For all points A through I, dose rates were computed at 0,1 and 2 meters from the edge of the trailer, and at 6 different elevations ranging from ground level to $305 \mathrm{~cm}$ (120 in.) above the ground.

Dose rates at some elevations in front of the trailer (point I and the driver location) depend on the thickness of the front steel shield. MCNP

calculations were made using three thicknesses, $2.5,7.6$ and $12.7 \mathrm{~cm}(1,3$ and 5 in.). Results of the dose rate calculations at points $A$ through $I$ are shown in Table 4.

The location of the driver was assumed to be $152 \mathrm{~cm}(60 \mathrm{in}$.) in front of the trailer, and offset $91 \mathrm{~cm}$ ( $36 \mathrm{in.)}$ from the trailer centerline. Two elevations were chosen as representative of the driver's height above the ground while in the cab of the truck. These elevations are $183 \mathrm{~cm}$ (72 in.) 
WHC-SD-TP-ANAL-007

Rev. 0

Page 9 of 17

and $244 \mathrm{~cm}$ (96 in.) above ground level. The computed dose rates at the driver's location as a function of shield thickness are given in Table 5. Any shielding provided by the truck cab and some other components, such as axles, wheels and frames, were not accounted for in the calculational mode?.

Table 4. Dose Rates around the Transport Trailer (Sheet 1)

\begin{tabular}{|c|c|c|c|c|}
\hline \multirow[b]{2}{*}{ Point ${ }^{a}$} & \multirow{2}{*}{$\begin{array}{c}\text { Elevation } \\
(\mathrm{cm})\end{array}$} & \multicolumn{3}{|c|}{ Dose Rate (mrem/hr) ${ }^{b}$} \\
\hline & & Contact & 1 meter & 2 meter \\
\hline A & $\begin{array}{r}0 \\
61 \\
122 \\
183 \\
244 \\
305 \\
\end{array}$ & $\begin{array}{l}3.1 \mathrm{E}+00 \\
4.0 \mathrm{E}+00^{*} \\
3.4 \mathrm{E}+00^{*} \\
3.0 \mathrm{E}+00 \\
2.1 \mathrm{E}-01^{*} \\
2.5 \mathrm{E}-01^{*}\end{array}$ & $\begin{array}{l}2.4 \mathrm{E}+00 \\
3.4 \mathrm{E}+00^{*} \\
2.8 \mathrm{E}+00^{\star} \\
2.4 \mathrm{E}+00 \\
1.6 \mathrm{E}+00 \\
4.9 \mathrm{E}-01^{\star}\end{array}$ & $\begin{array}{l}1.9 \mathrm{E}+00 \\
2.4 \mathrm{E}+00^{\star} \\
2.2 \mathrm{E}+00 \\
2.0 \mathrm{E}+00 \\
2.0 \mathrm{E}+00 \\
3.4 \mathrm{E}-01^{*}\end{array}$ \\
\hline B & $\begin{array}{r}0 \\
61 \\
122 \\
183 \\
244 \\
305 \\
\end{array}$ & $\begin{array}{l}3.1 \mathrm{E}+00 \\
3.6 \mathrm{E}+00^{*} \\
3.5 \mathrm{E}+00^{*} \\
3.9 \mathrm{E}+00^{*} \\
6.3 \mathrm{E}-01^{*} \\
2.3 \mathrm{E}-01^{*}\end{array}$ & $\begin{array}{l}2.4 \mathrm{E}+00 \\
2.9 \mathrm{E}+00^{\star} \\
2.8 \mathrm{E}+00^{\star} \\
2.5 \mathrm{E}+00 \\
1.7 \mathrm{E}+00 \\
4.1 \mathrm{E}-01^{\star}\end{array}$ & $\begin{array}{l}1.9 \mathrm{E}+00 \\
2.3 \mathrm{E}+00 \\
2.2 \mathrm{E}+00 \\
2.0 \mathrm{E}+00 \\
2.0 \mathrm{E}+00 \\
5.3 \mathrm{E}-01 \\
\end{array}$ \\
\hline C & $\begin{array}{r}0 \\
61 \\
122 \\
183 \\
244 \\
305 \\
\end{array}$ & $\begin{array}{l}3.1 \mathrm{E}+00 \\
3.5 \mathrm{E}+00 \\
3.4 \mathrm{E}+00^{*} \\
3.5 \mathrm{E}+00^{*} \\
1.1 \mathrm{E}+00^{*} \\
1.0 \mathrm{E}+00\end{array}$ & $\begin{array}{l}3.2 \mathrm{E}+00 \\
3.4 \mathrm{E}+00 \\
3.2 \mathrm{E}+00 \\
2.9 \mathrm{E}+00 \\
2.8 \mathrm{E}+00 \\
2.8 \mathrm{E}+00\end{array}$ & $\begin{array}{l}3.3 \mathrm{E}+00 \\
3.5 \mathrm{E}+00 \\
3.3 \mathrm{E}+00 \\
3.1 \mathrm{E}+00 \\
3.2 \mathrm{E}+00 \\
3.9 \mathrm{E}+00 \\
\end{array}$ \\
\hline D & $\begin{array}{r}0 \\
61 \\
122 \\
183 \\
244 \\
305 \\
\end{array}$ & $\begin{array}{l}2.4 \mathrm{E}+01 \\
2.6 \mathrm{E}+01 \\
2.0 \mathrm{E}+01 \\
1.5 \mathrm{E}+01 \\
3.9 \mathrm{E}+00 \\
3.7 \mathrm{E}+00\end{array}$ & $\begin{array}{l}2.4 \mathrm{E}+01 \\
2.6 \mathrm{E}+01 \\
2.0 \mathrm{E}+01 \\
1.4 \mathrm{E}+01 \\
1.2 \mathrm{E}+01 \\
1.2 \mathrm{E}+01\end{array}$ & $\begin{array}{l}2.4 \mathrm{E}+01 \\
2.4 \mathrm{E}+01 \\
1.9 \mathrm{E}+01 \\
1.6 \mathrm{E}+01 \\
1.6 \mathrm{E}+01 \\
1.8 \mathrm{E}+01 \\
\end{array}$ \\
\hline$E$ & $\begin{array}{r}0 \\
61 \\
122 \\
183 \\
244 \\
305 \\
\end{array}$ & $\begin{array}{l}5.5 \mathrm{E}+02 \\
7.0 \mathrm{E}+02 \\
7.8 \mathrm{E}+02 \\
8.2 \mathrm{E}+02 \\
4.7 \mathrm{E}+02 \\
4.9 \mathrm{E}+02 \\
\end{array}$ & $\begin{array}{l}4.2 \mathrm{E}+02 \\
5.1 \mathrm{E}+02 \\
4.9 \mathrm{E}+02 \\
4.0 \mathrm{E}+02 \\
4.4 \mathrm{E}+02 \\
4.7 \mathrm{E}+02\end{array}$ & $\begin{array}{l}3.1 \mathrm{E}+02 \\
3.3 \mathrm{E}+02 \\
3.0 \mathrm{E}+02 \\
3.0 \mathrm{E}+02 \\
3.1 \mathrm{E}+02 \\
3.4 \mathrm{E}+02 \\
\end{array}$ \\
\hline F & $\begin{array}{r}0 \\
61 \\
122 \\
183 \\
244 \\
305 \\
\end{array}$ & $\begin{array}{l}1.3 E+03 \\
1.3 E+03 \\
1.5 E+03 \\
1.5 E+03 \\
8.8 E+02 \\
8.7 E+02\end{array}$ & $\begin{array}{l}7.7 \mathrm{E}+02 \\
9.5 \mathrm{E}+02 \\
9.1 \mathrm{E}+02 \\
7.6 \mathrm{E}+02 \\
8.0 \mathrm{E}+02^{\mathrm{c}} \\
8.3 \mathrm{E}+02\end{array}$ & $\begin{array}{l}6.7 \mathrm{E}+02 \\
6.1 \mathrm{E}+02 \\
5.5 \mathrm{E}+02 \\
5.5 \mathrm{E}+02 \\
5.6 \mathrm{E}+02 \\
6.0 \mathrm{E}+02 \\
\end{array}$ \\
\hline
\end{tabular}

a See Figure 1 for location of points.

c Interpolated value - not computed explicitly by MCNP.

* Interpolated value - not th uncertainty estimates greater than $10 \%$. Use values as order-ofmagnitude indicators only. 
WHC-SD-TP-ANAL-007

Rev. 0

Page 10 of 17

Table 4. Dose Rates around the Transport Trailer (Sheet 2)

\begin{tabular}{|c|c|c|c|c|}
\hline \multirow[b]{2}{*}{ Point } & \multirow{2}{*}{$\begin{array}{c}\text { Elevation } \\
(\mathrm{cm})\end{array}$} & \multicolumn{3}{|c|}{ Dose Rate (mrem/hr) ${ }^{b}$} \\
\hline & & Contact & 1 meter & 2 meter \\
\hline G & $\begin{array}{r}0 \\
61 \\
122 \\
183 \\
244 \\
305 \\
\end{array}$ & $\begin{array}{l}5.6 \mathrm{E}+02 \\
7.0 \mathrm{E}+02 \\
7.8 \mathrm{E}+02 \\
8.2 \mathrm{E}+02 \\
4.6 \mathrm{E}+02 \\
4.4 \mathrm{E}+02 \\
\end{array}$ & $\begin{array}{l}4.7 \mathrm{E}+02 \\
5.0 \mathrm{E}+02 \\
4.8 \mathrm{E}+02 \\
4.0 \mathrm{E}+02 \\
4.2 \mathrm{E}+02 \\
4.3 \mathrm{E}+02 \\
\end{array}$ & $\begin{array}{l}3.2 \mathrm{E}+02 \\
3.4 \mathrm{E}+02 \\
3.0 \mathrm{E}+02 \\
3.0 \mathrm{E}+02 \\
3.0 \mathrm{E}+02 \\
3.2 \mathrm{E}+02\end{array}$ \\
\hline $\mathrm{H}$ & $\begin{array}{r}0 \\
61 \\
122 \\
183 \\
244 \\
305 \\
\end{array}$ & $\begin{array}{l}2.5 \mathrm{E}+02 \\
2.7 \mathrm{E}+02 \\
2.4 \mathrm{E}+02 \\
1.9 \mathrm{E}+02 \\
4.1 \mathrm{E}+02 \\
4.5 \mathrm{E}+02\end{array}$ & $\begin{array}{l}2.2 \mathrm{E}+02 \\
2.4 \mathrm{E}+02 \\
2.1 \mathrm{E}+02 \\
2.2 \mathrm{E}+02 \\
2.6 \mathrm{E}+02 \\
2.6 \mathrm{E}+02 \\
\end{array}$ & $\begin{array}{l}1.8 \mathrm{E}+02 \\
1.9 \mathrm{E}+02 \\
1.8 \mathrm{E}+02 \\
1.9 \mathrm{E}+02 \\
1.9 \mathrm{E}+02 \\
2.0 \mathrm{E}+02\end{array}$ \\
\hline $\begin{array}{l}\text { I } 2.5 \mathrm{~cm} \\
\text { th. front } \\
\text { shield }\end{array}$ & $\begin{array}{r}0 \\
61 \\
122 \\
183 \\
244 \\
305 \\
\end{array}$ & $\begin{array}{l}2.5 \mathrm{E}+02 \\
2.8 \mathrm{E}+02 \\
2.8 \mathrm{E}+02 \\
3.0 \mathrm{E}+02 \\
1.2 \mathrm{E}+02 \\
1.8 \mathrm{E}+02\end{array}$ & $\begin{array}{l}1.4 \mathrm{E}+02 \\
1.6 \mathrm{E}+02 \\
1.6 \mathrm{E}+02 \\
1.2 \mathrm{E}+02 \\
1.3 \mathrm{E}+02 \\
1.4 \mathrm{E}+02\end{array}$ & $\begin{array}{l}9.0 \mathrm{E}+01 \\
9.9 \mathrm{E}+01 \\
8.3 \mathrm{E}+01 \\
6.9 \mathrm{E}+01 \\
7.4 \mathrm{E}+01 \\
7.8 \mathrm{E}+01 \\
\end{array}$ \\
\hline $\begin{array}{l}\text { I } \\
\text { w/ } 7.6 \mathrm{~cm} \\
\text { th. front } \\
\text { shield }\end{array}$ & $\begin{array}{r}0 \\
61 \\
122 \\
183 \\
244 \\
305 \\
\end{array}$ & $\begin{array}{l}2.6 \mathrm{E}+02 \\
3.0 \mathrm{E}+02 \\
2.9 \mathrm{E}+02 \\
3.2 \mathrm{E}+02 \\
9.4 \mathrm{E}+00 \\
1.5 \mathrm{E}+01 \\
\end{array}$ & $\begin{array}{l}1.5 \mathrm{E}+02 \\
1.7 \mathrm{E}+02 \\
1.6 \mathrm{E}+02 \\
7.8 \mathrm{E}+01 \\
3.0 \mathrm{E}+01 \\
2.5 \mathrm{E}+01\end{array}$ & $\begin{array}{l}9.2 \mathrm{E}+01 \\
9.8 \mathrm{E}+01 \\
6.7 \mathrm{E}+01 \\
3.1 \mathrm{E}+01 \\
2.3 \mathrm{E}+01 \\
2.1 \mathrm{E}+01 \\
\end{array}$ \\
\hline $\begin{array}{l}\text { w/ } 12.7 \mathrm{~cm} \\
\text { th. front } \\
\text { shield }\end{array}$ & $\begin{array}{r}0 \\
61 \\
122 \\
183 \\
244 \\
305\end{array}$ & $\begin{array}{l}2.6 \mathrm{E}+02 \\
3.0 \mathrm{E}+02 \\
2.9 \mathrm{E}+02 \\
3.2 \mathrm{E}+02 \\
3.6 \mathrm{E}+00 \\
3.5 \mathrm{E}+01\end{array}$ & $\begin{array}{l}1.6 \mathrm{E}+02 \\
1.6 \mathrm{E}+02 \\
1.6 \mathrm{E}+02 \\
7.6 \mathrm{E}+01 \\
2.7 \mathrm{E}+01 \\
1.6 \mathrm{E}+01\end{array}$ & $\begin{array}{l}9.1 \mathrm{E}+01 \\
9.6 \mathrm{E}+01 \\
5.4 \mathrm{E}+01 \\
3.0 \mathrm{E}+01 \\
2.0 \mathrm{E}+01 \\
1.7 \mathrm{E}+01\end{array}$ \\
\hline
\end{tabular}

a See Figure 1 for location of points. 
WHC-SD-TP-ANAL-007

Rev. 0

Page 11 of 17

Table 5. Dose Rates at Driver's Location as a Function of Front Shield Thickness

\begin{tabular}{|c|c|c|c|}
\hline \multirow{2}{*}{$\begin{array}{l}\text { Elevation } \\
\text { above Ground }\end{array}$} & \multicolumn{3}{|c|}{ Dose Rate (mrem/hr) } \\
\hline & $2.5 \mathrm{~cm}\left(1^{\prime \prime}\right)$ & $7.6 \mathrm{~cm}\left(3^{\prime \prime}\right)$ & $12.7 \mathrm{~cm}\left(5^{\prime \prime}\right)$ \\
\hline $183 \mathrm{~cm}\left(72^{\prime \prime}\right)$ & 77 & 42 & 40 \\
\hline $244 \mathrm{~cm}\left(96^{\prime \prime}\right)$ & 78 & 25 & 22 \\
\hline
\end{tabular}

The MCNP uncertainty estimates associated with most dose rates given in Tables 4 and 5 are less than $10 \%$, indicating they are probably reliable estimates. However, at locations $A, B$ and $C$ in Figure 1 , near the rear of the trailer, uncertainty estimates ranged up to $70 \%$. The high uncertainties are due to low dose rates. Because relatively few photons reached these locations in the MCNP simulation, the statistics were poor. Dose rates in Table 4 with uncertainties larger than $10 \%$ are flagged. The flagged values should be used as order-of-magnitude estimates only.

MCNP transport calculations indicated that the effect of ground shine is very significant (16 to $18 \mathrm{mrem} / \mathrm{hr}$ ) at the driver's location. Ground shine was also relatively significant at the rear of the trailer, where dose rates are lowest. There, ground shine contributed $2-3 \mathrm{mrem} / \mathrm{hr}$ to the dose rate. Neglecting ground shine, dose rates behind the trailer were computed to be less than $1 \mathrm{mrem} / \mathrm{hr}$ (based on point-kernel results). At the side of the trailer near the source region, ground shine did not appear to contribute significantly to the dose rate.

\subsection{SHIELDING EVALUATION AND CONCLUSIONS}

The calculated peak dose rates for the front, sides and back of the trailer are summarized in Table 6 . Dose rates along the side are as high as 1,500 $\mathrm{mrem} / \mathrm{hr}$. In general, contact dose rates peak near head level (183 cm or 72 in.). This is just below the elevation of the trailer bed and the shields mounted on it (see Figure 2). These shields are oniy partially effective in reducing dose rates around the trailer because of the minimal bottom shielding and the height of the trailer bed above the ground $(228 \mathrm{~cm}$ or $90 \mathrm{in.})$.

With the current design, the shields at the front of the trailer cannot reduce the dose rate at the driver's location to $2 \mathrm{mrem} / \mathrm{hr}$. Additional bottom shielding or front shielding that extends well below the elevation of the trailer bed is needed. If the front shieid is extended down to eliminate both the direct exposure from beneath the shield and ground shine, and its steel thickness is increased to $13 \mathrm{~cm}$ ( 5 in.), the driver's dose rate would be reduced to about $1 \mathrm{mrem} / \mathrm{hr}$ with the source term used in this analysis. Also, if the side shields were extended down from the trailer bed, the peak contact dose rate at the side of the trailer could be reduced from $1,500 \mathrm{mrem} / \mathrm{hr}$ to about $870 \mathrm{mrem} / \mathrm{hr}$, without increasing shield thickness.

Dose rates at the rear of the trailer are very low compared to peak dose rates on the side and front of the trailer, as shown in Table 6 . The greater distance from the radiation source and the shielding effect of the low-density grout filler are the main reasons for this. 
As mentioned in Section 3.0, photon scattering in air (sky shine) was not accounted for in the results shown in Tables 4,5 and 6. A separate calculation indicated that the effect of sky shine is relatively small, but not insignificant at some locations. In particular, accounting for sky shine adds up to $2 \mathrm{mrem} / \mathrm{hr}$ to the dose rate near the rear of the trailer, and 6 to 7 mrem/hr at the driver's 1ocation when there is a $12.7 \mathrm{~cm}(5 \mathrm{in}$.) thick shield at the front of the trailer. Thus, final shielding analyses of the LLCE transportation package should consider the effects of sky shine.

Table 6. Summary of Peak Dose Rates at the Front, Sides and Back of the Transportation Package Trailer

\begin{tabular}{|c|c|c|c|}
\hline \multirow[b]{2}{*}{ Location } & \multicolumn{3}{|c|}{ Dose Rate (mrem/hr) } \\
\hline & Contact & 1 meter & 2 meter \\
\hline $\begin{array}{l}\text { Peak Side } \\
\text { (point F) }\end{array}$ & 1500 & 950 & 670 \\
\hline $\begin{array}{l}\text { Center Line, Back } \\
\text { (point A) }\end{array}$ & 4.0 & 3.4 & 2.4 \\
\hline $\begin{array}{l}\text { Off Center, Back } \\
\text { (point } B \text { ) }\end{array}$ & 3.9 & 2.9 & 2.3 \\
\hline $\begin{array}{l}\text { Center Line, } \\
\text { Front (point I) } \\
-\quad 2.5 \mathrm{~cm} \text { shield } \\
-\quad 5.1 \mathrm{~cm} \text { shield } \\
-\quad 7.6 \mathrm{~cm} \text { shield } \\
\end{array}$ & $\begin{array}{l}300 \\
320 \\
320 \\
\end{array}$ & $\begin{array}{l}160 \\
170 \\
160 \\
\end{array}$ & $\begin{array}{l}99 \\
98 \\
96 \\
\end{array}$ \\
\hline
\end{tabular}

See figure 1 for the location of each point

$b$ Thicknesses of the $183 \mathrm{crn}$ ( 72 in.) tall front shield.

\subsection{REFERENCES}

1. Memo, H. J. Goldberg to J. S. Burgess, "Safety Class Analys is of Long Length Equipment Packaging," 8M730-HJG-95-012, Apri1 13, 1995.

2. Rittmann, P. D., ISO-PC Version 1.98 - User's Guide, WHC-SD-WM-UM-030, Rev 0, May 1995.

3. Memo, J. V. Nelson to J. R. Green, "Estimation of Neutron Dose Rates from Nuclear Waste Packages," 8M730-JVN-96-007, March 8, 1996.

4. Carter, L. L., Certification of MCNP Version 4A for WHC Computer Platforms, WHC-SD-MP-SWD-30001, Rev. 7, ECN 605701, Westinghouse Hanford Company, Richland, Washington, January, 1995.

5. Breismeister, J. F., Editor, MCNP - A General Monte Carlo N-Particle Transport Code, Version $4 a$, Los ATamos National Laboratory report LA12625, Los Alamos, New Mexico, 1993. 
WHC-SD-TP-ANAL-007

Rev. 0

Page 13 of 17

\section{APPENDIX
LISTING OF SAMPLE MCNP INPUT FILE}

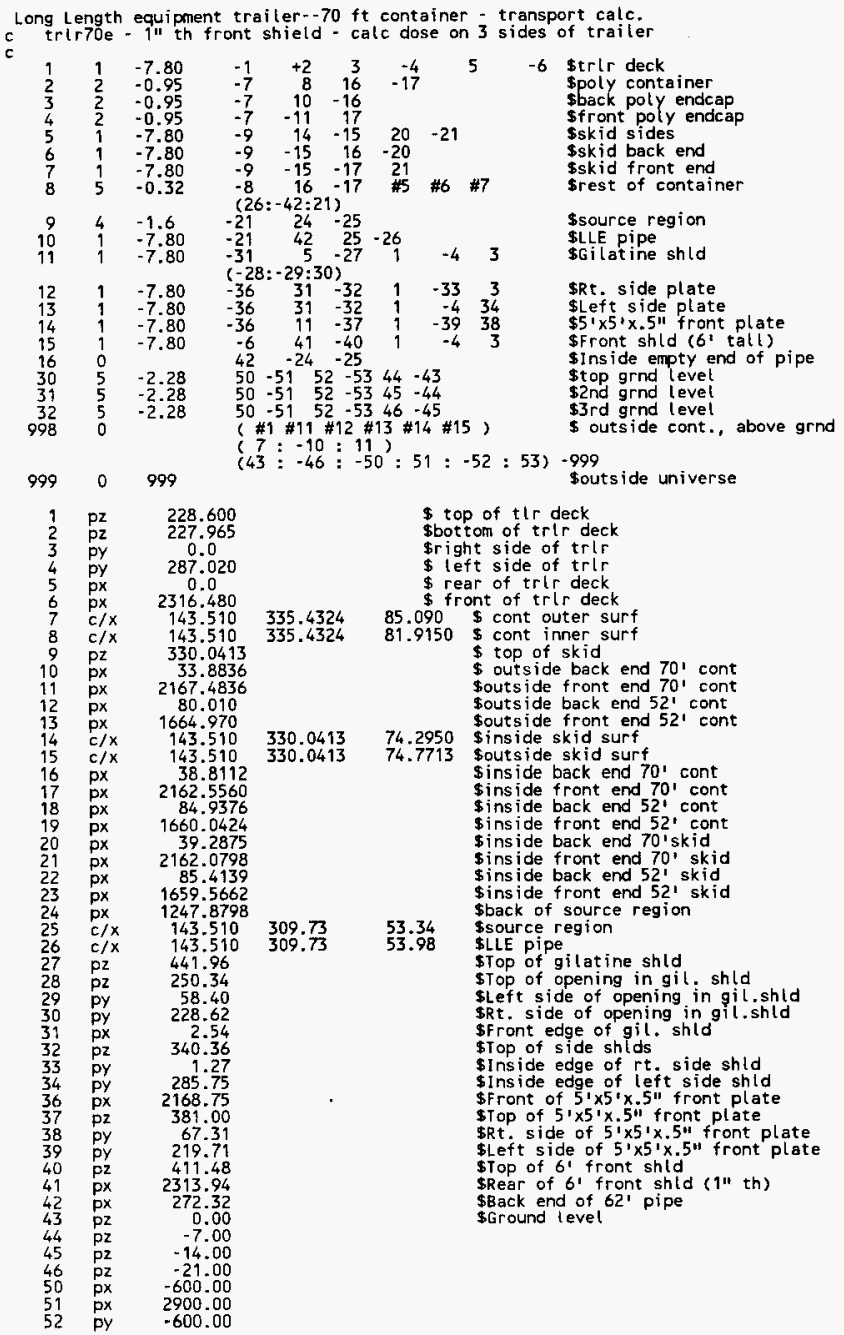




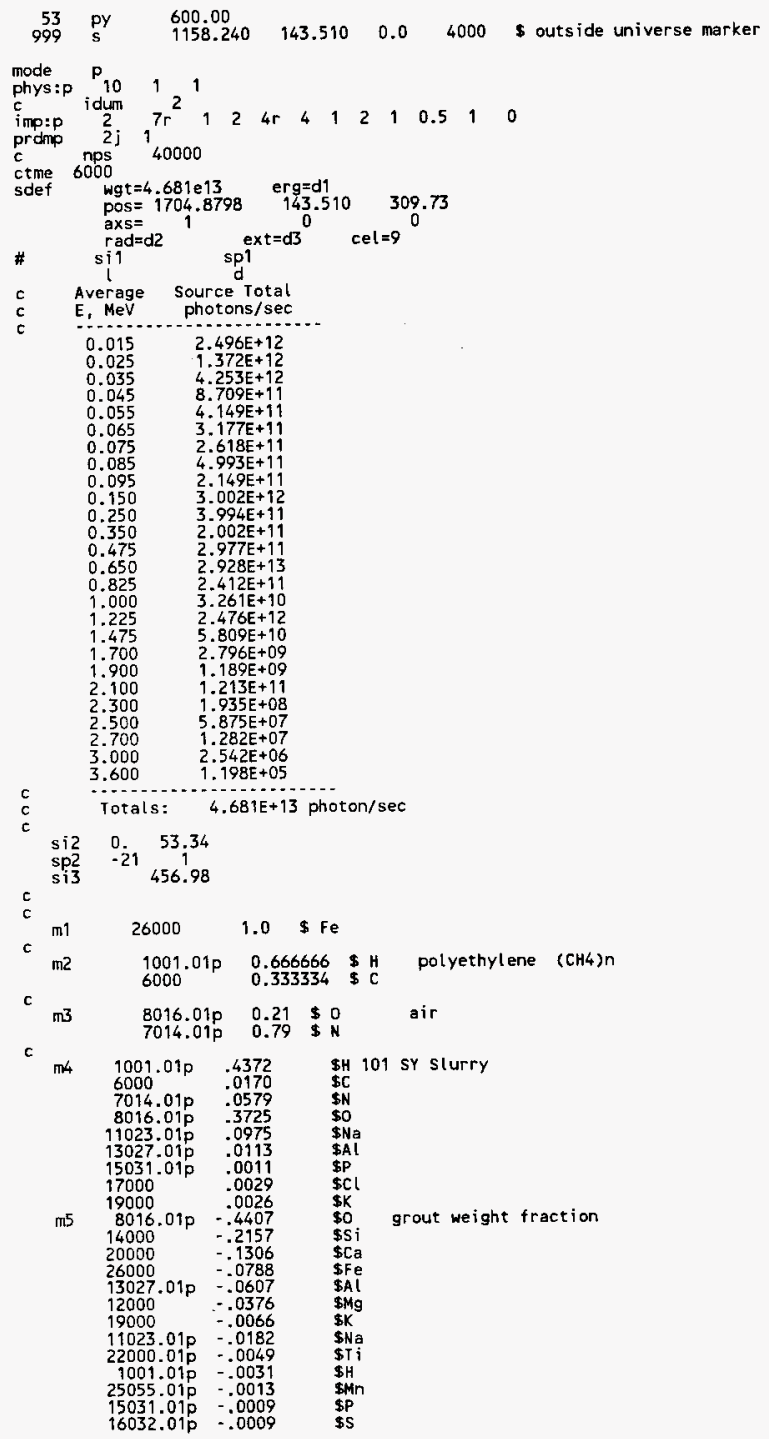




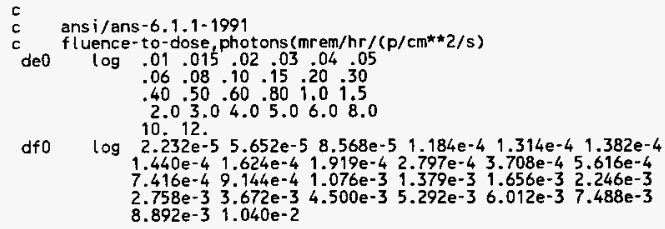


WHC-SD-TP-ANAL-007

Rev. 0

Page 16 of 17

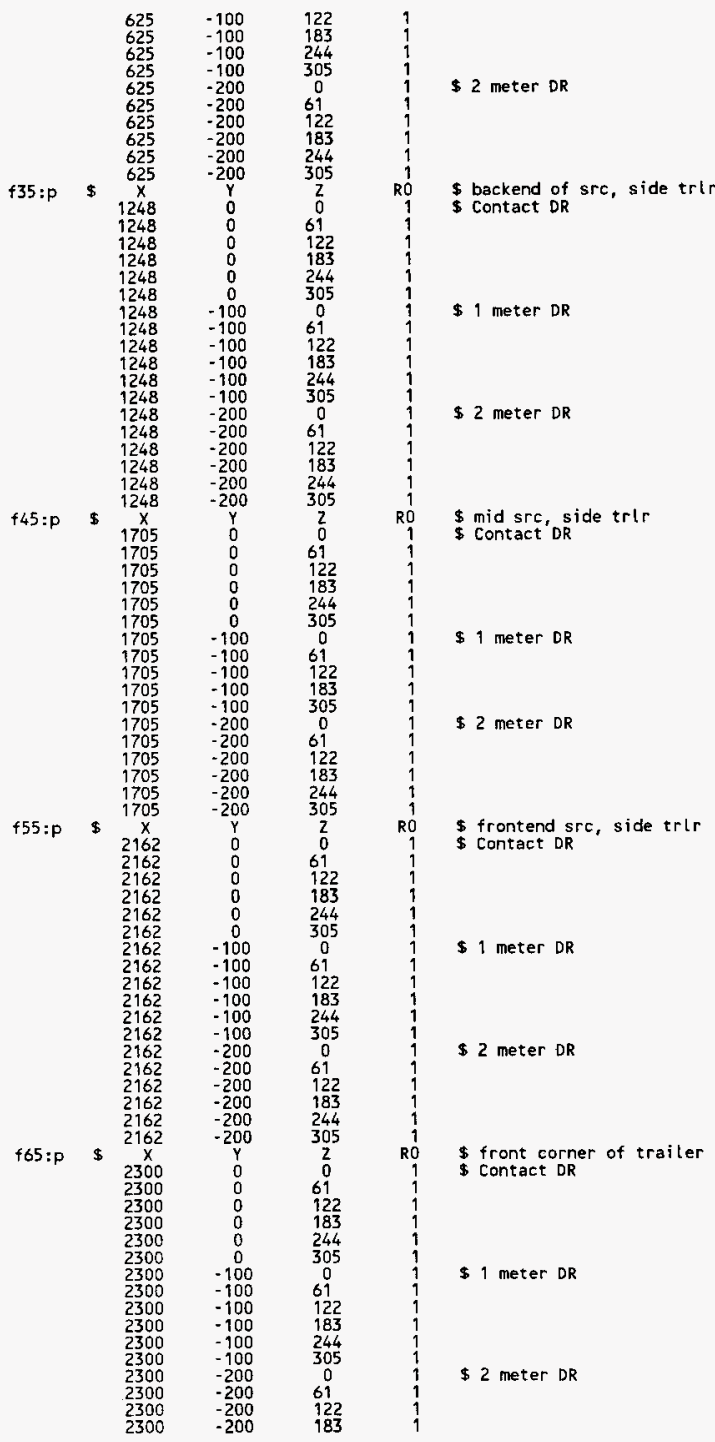


WHC-SD-TP-ANAL-007

Rev. 0

Page 17 of 17

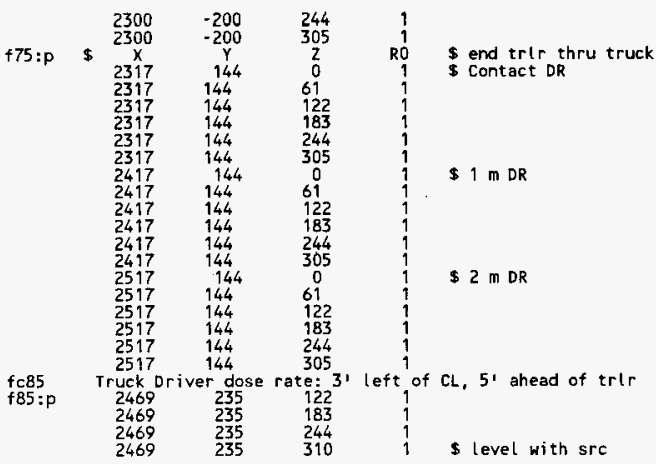




\section{CHECKLIST FOR INDEPENDENT TECHNICAL REVIEW}

DOCUMENT REVIEWED

NUMBER: WHC-SD-TP-ANAL-007

TITLE: $\quad$ SHIELDING ANALYSIS OF THE LONG LENGTH CONTAMINATED EQUIPMENT IRANSPORTATION PACKAGE

Reviewer(s): R. L. Simons

I. Method(s) of Review

$(\checkmark)$ Input data checked for accuracy

$\left\{\begin{array}{l}\text { Independent calculation performed } \\ \text { Ind }\end{array}\right.$ Hand calculation

Alternate computer code:

Comparison to experiment or previous results Alternate method (define)

II. Checklist (either check or enter NA if not applied)

(-) Task completely defined

(- Activity consistent with task specification

$-\{$ Necessary assumptions explicitly stated and supported

- - Resources properly identified and referenced

(-) Resource documentation appropriate for this application

(-) Input data explicitly stated

- Input data verified to be consistent with original source

(-) Geometric model adequate representation of actual geometry

(-) Material properties appropriate and reasonable

NA) Mathematical derivations checked including dimensional consistency

WA Hand calculations checked for errors

(-I) Assumptions explicitly stated and justified

(-) Computer software appropriate for task and used within range of validity

(N/) Use of resource outside range of established validity is justified

(N) Software runstreams correct and consistent with results

(N) Software output consistent with input

WA Results consistent with applicable previous experimental or analytical findings

(-) Results and conclusions address all points and are consistent with task requirements and/or established limits or criteria

(-) Conclusions consistent with analytical results and established limits

$\rightarrow$ Uncertainty assessment appropriate and reasonable

(NAf) Other (define)

III. Comments:

IV. REVIEWER:

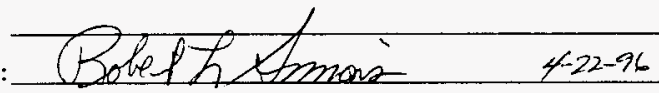


WHC-SD-TP-ANAL-007

Rev. 0

Att. -2

\section{CHECKLIST FOR INDEPENDENT TECHNICAL REVIEW}

DOCUMENT REVIEWED

NUMBER: WHC-SD-TP-ANAL-007

TITLE: $\quad$ SHIELDING ANALYSIS OF THE LONG LENGTH CONTAMINATED EQUIPMENT TRANSPORTATION PACKAGE

Reviewer(s): D. E. Lessor

I. Method(s) of Review

(x) Input data checked for accuracy

$\left\{\begin{array}{l}\text { Independent calculation performed } \\ \text { Hand calculation }\end{array}\right.$

Alternate computer code:

$\left\{x\left\{\begin{array}{l}\text { Comparison to experiment or previous results } \\ \text { Alternate method (define) fll aspects of the writing and included }\end{array}\right.\right.$

II. Checklist (either check or enter NA if not applied) numbers checked

(NA) Task completely defined

(NA) Activity consistent with task specification

(NA) Necessary assumptions explicitiy stated and supported

( $X$ Resources properly identified and referenced

(NA) Resource documentation appropriate for this application

(x) Input data explicitly stated

$\{x$ Input data verified to be consistent with original source

(NA) Geometric model adequate representation of actual geometry

(NA Material properties appropriate and reasonable

(NA) Mathematical derivations checked including dimensional consistency

(x) Hand calculations checked for errors

(x) Assumptions explicitly stated and justified

(x) Computer software appropriate for task and used within range of validity

(NA) Use of resource outside range of established validity is justified

(x) Software runstreams correct and consistent with results

$(x)$ Software output consistent with input

(NA) Results consistent with applicable previous experimental or analytical findings

(NA) Results and conclusions address all points and are consistent with task requirements and/or established limits or criteria

(NA) Conclusions consistent with analytical results and established limits

(NA) Uncertainty assessment appropriate and reasonable

( Other (define)

III. Comments:

IV. REVIEWER: $\%$ acenor $4 / 17 / 96$ 


\section{DISTRIBUTION SHEET}

\begin{tabular}{|c|c|c|c|c|c|}
\hline \multirow{2}{*}{$\begin{array}{l}\text { To } \\
\text { Distribution }\end{array}$} & \multirow{2}{*}{\multicolumn{3}{|c|}{$\begin{array}{l}\text { From } \\
\text { Nuclear Physics and Shielding }\end{array}$}} & \multicolumn{2}{|c|}{ Page 1 of 1} \\
\hline & & & & \multicolumn{2}{|c|}{ Date May 6, 1996} \\
\hline \multicolumn{4}{|l|}{ Project Title/Work Order } & \multicolumn{2}{|c|}{ EDT No. 603245} \\
\hline \multicolumn{4}{|c|}{$\begin{array}{l}\text { Shielding Analysis of the Long Length Contaminated Equipment } \\
\text { Transportation Package }\end{array}$} & \multicolumn{2}{|c|}{ ECN No. NA } \\
\hline Name & MSIN & $\begin{array}{c}\text { Text } \\
\text { With All } \\
\text { Attach. }\end{array}$ & Text Only & $\begin{array}{l}\text { Attach./ } \\
\text { Appendix } \\
\text { Only }\end{array}$ & $\begin{array}{c}\text { EDT/ECN } \\
\text { Only }\end{array}$ \\
\hline
\end{tabular}

J. G. Field

J. R. Green

J. Greenborg (2 copies)

W. A. McCormick

J. V. Nelson

A. L. Ramble

R. L. Simons

R. E. Traister

E. M. Veith

Central Files (original +3)
G1-11 $X$

G1-11 $X$

HO-35 X

G1-11 $X$

HO-35 X

A3-38 $X$

HO-35 X

B3-63 $X$

H5-68 $X$

A3-88 $X$ 